\title{
PENGALAMAN KOMUNIKASI KELUARGA ISTRI YANG BERPENDAPATAN LEBIH BESAR DARI SUAMI
}

\begin{abstract}
Nurul Utami*
Universitas Indonesia

\section{ABSTRAK}

Penelitian ini bertujuan untuk menganalisis pengalaman komunikasi keluarga istri yang berpendapatan lebih besar dari suami di kota Palembang. Untuk menjawab permasalahan tersebut, dilakukan analisis terhadap pokok-pokok pertanyaan penelitian, yaitu: makna ekspektasi peran dalam pernikahan, motif bekerja, dan pengalaman komunikasi istri yang berpendapatan lebih besar dari suami dalam rangka mempertahankan hubungan keluarga yang harmonis. Pendekatan yang digunakan dalam penelitian ini adalah kualitatif dengan studi fenomenologi. Hasil penelitian menunjukkan makna yang diberikan istri yang berpendapatan lebih besar dari suami dan lebih berperan dalam menyokong perekonomian keluarga mengenai ekspektasi peran dalam pernikahan dengan melihat kebaikan yang ada pada diri suami, yaitu: kasih sayang suami yang diwujudkan dengan penghargaan dan perhatian yang diberikan pada istri yang telah bersedia lebih berperan dalam menyokong perekonomian keluarga; kesadaran dan kesediaan suami untuk melaksanakan pekerjaaan domestik rumah tangga sebagai kompensasi atas 'pertukaran peran' yang dijalani, dan; kesungguhan suami dalam menunaikan tanggung jawab sebagai kepala keluarga yang tetap berusaha demi mencapai tingkat pendapatan yang lebih baik. Motif bekerja para istri yang berpendapatan lebih besar dari suami adalah memanfaatkan ilmu, pengalaman keterbatasan ekonomi keluarga di masa lalu, kemandirian finansial, demi taraf hidup keluarga yang lebih baik, berperan menafkahi keluarga, dan kesepakatan dengan suami. Mereka memaknai arti keluarga harmonis dan berusaha mempertahankannya dengan cara menjaga hubungan baik dalam relasi suamiistri; kerja sama pengaturan keuangan rumah tangga antara suami-istri; menggunakan otoritas sebagai ibu terhadap anaknya secara proporsional, dan; menghindari/meluruskan kesalahpahaman serta menjaga hubungan baik dengan orang tua dari kedua belah pihak sebagai upaya untuk menjaga keharmonisan keluarga.
\end{abstract}

Kata-kata kunci: Pengalaman Komunikasi, Keluarga, Makna, Ekspektasi Peran, Motif.

\section{FAMILY COMMUNICATION EXPERIENCES WHICH WIFE'S INCOME IS GREATER THAN HUSBAND}

\section{ABSTRACT}

This study aims to analyze family communication experiences which wife's income is greater than husband in Palembang. To answer these problems, an analysis of the main points of research questions, namely: the meaning expectations of roles in marriage, motives to work, and wives' communication experience earn more than their husbands in order to maintain a harmonious family relationship. The approach used in this study is a qualitative phenomenological study. The results showed the meaning given by wives who earn more than husbands and taking role in supporting the economy of the family regarding expectations for roles in marriage to see the kindness in their husband, namely affection husband realized with respect and attention given to the wife has been willing to be instrumental in supporting the family economy; husband's awareness and willingness to carry out domestic household employment as compensation for 'exchange of roles' that followed, and; husband seriousness in fulfilling the responsibility as head of the family who is still trying to achieve a better level of income. Motif working wives earn more than husbands are utilizing the knowledge, experience family economic limitations in the past, financial independence, the standard of living for the sake of a better family, act to provide for the family, and deal with her husband. They interpret the meaning of a harmonious family and trying to maintain it in a way to maintain good relations in the relationship of husband and wife; cooperation household financial arrangements between the spouses; using authority as a mother to her child in proportion, and; avoid / straighten out misunderstandings and maintain a good relationship with the parents of both sides in an effort to maintain family harmony.

Keywords: Communications Experience, Family, Meaning, Role Expectation, Motives.

\footnotetext{
${ }^{\star}$ Korespondensi: Nurul Utami, S.Sos., M.I.Kom. Departemen Ilmu Komunikasi Fakultas Ilmu Sosial dan Ilmu Politik Universitas Indonesia, Depok Jawa Barat.Email: cutnurulutami91@gmail.com
} 


\section{PENDAHULUAN}

Memiliki sosok seorang suami ideal merupakan harapan banyak perempuan. Namun, ketika harapan berbeda dengan apa yang diperoleh dalam kenyataan, timbul berbagai reaksi dan cara yang dilakukan untuk dapat menerima keadaan dan terus menjalani kehidupan rumah tangga yang sudah dibina bersama. Bahkan, kesiapan sudah dimiliki oleh seorang istri untuk menerima kondisi dan peran yang berbeda dari harapan mengenai pasangan idaman. Kasih sayang dan kepercayaan terhadap upaya nyata dari pasangan untuk menjadi lebih baik dinilai sebagai hal yang menumbuhkan penerimaan.

Harapan mengenai sosok suami ideal tersebut yakni memiliki kemapanan ekonomi sehingga menjamin kenyamanan hidup rumah tangga. Suami yang memiliki pendapatan yang lebih besar, mampu menjadi imam keluarga agar dapat mengayomi, juga menjadi kriteria ideal yang diharapkan oleh informan penelitian ini. Namun demikian, kenyataan yang berbeda dengan kriteria yang diharapkan mengenai sosok suami, diterima sebagai jalan jodoh yang sudah ditetapkan. Akhirnya, keputusan untuk hidup bersama dalam pernikahan dan menerima kondisi pasangan dengan pendapatan yang tidak lebih besar dari dirinya, menjadi pilihan yang telah dijalani oleh para informan penelitian ini. Sebagai perempuan, keterbukaan, kasih sayang, dan komitmen pasangan untuk menjadi suami yang baik menjadi pertimbangan yang menurunkan ekspektasi mengenai jumlah pendapatan suami.

Pada kenyataannya, kondisi sosialekonomi di negara Indonesia yang seringkali mengalami lonjakan yang signifikan, tak jarang menuntut individu-individu dalam rumah tangga untuk bekerja dan memperoleh pendapatan lebih demi kelangsungan hidup keluarga. Persaingan kerja yang semakin ketat menyebabkan terjadinya perubahan peran dalam keluarga. Peran istri yang bekerja di ranah publik terasa makin dibutuhkan. Pandangan tradisional mengenai keluarga tidak lagi menjadi pakem yang berlaku saklek dalam masyarakat. Hal ini dibuktikan dengan munculnya fenomena istri bekerja sebagai dampak dari meningkatnya industrialisasi, yang dapat memudarkan ideologi, kultur serta batas-batas kebangsaan suatu negara (dalam Ihromi, 1990: 140).

Para perempuan yang memutuskan untuk bekerja bahkan sejak masih hidup melajang mengakui bahwa bekerja merupakan sarana untuk memanfaatkan ilmu yang telah diperoleh hingga ke bangku pendidikan tinggi. Cita-cita untuk memiliki kemandirian finansial, serta keterbatasan taraf hidup keluarga di masa lalu juga mendorong para perempuan ini untuk memiliki pendapatan secara mandiri. Pekerjaan ini tetap mereka geluti sampai mereka sudah menikah dan membangun keluarga sendiri.

Fenomena yang kemudian muncul seiring dengan semakin banyaknya istri yang bekerja adalah jumlah pendapatan yang lebih besar yang mereka peroleh dibandingkan pendapatan suami. Walau sudah menerima konsekuensi atas kondisi kesenjangan pendapatannya dengan suami, para istri ini tidak jarang terpengaruh oleh tanggapan lingkungan sekitar yang membuat dirinya merasa tidak nyaman dan mempertanyakan kondisi yang dihadapi sebagai istri yang mempunyai suami dengan pendapatan lebih rendah. Kondisi dan tanggapan temanteman di lingkungan pekerjaan serta keluarga dinilai berpotensi memicu konflik batin maupun bibitkonflik yang dapat mengusik keharmonisan hidup berkeluarga.

Di sisi lain, berdasarkan hasil penelitian, kaum laki-laki melihat kesuksesan istri sebagai kegagalannya sendiri. Demikian penjelasan Kate Ratliff, $\mathrm{PhD}$, dari Universitas California. Hal ini adalah contoh persoalan psikologis yang bisa muncul pada suami ketika pendapatan istri lebih besar dari suami, atau karir istri lebih melejit daripada suami, atau posisi dan kedudukan istri di tempat kerja lebih tinggi dari suami. Muncul semacam rasa minder atau rasa bersalah atau rasa gagal menempatkan diri sebagai suami, sehingga berpeluang melahirkan konflik (Kompasiana, 2015).

Menurut sebuah survei dari World Value, ketika istri memiliki pendapatan yang lebih besar dari suami, biasanya menimbulkan beberapa masalah seperti kurang bahagia, lebih sering terjadi perselisihan dalam pernikahan, dan bahkan dalam beberapa kasus, pasangan lebih memilih untuk bercerai. Adapun studi yang dilakukan oleh tim dari American Psychological Association menunjukkan, 
kesuksesan karir istri dapat menjadi sumber konflik dalam rumah tangga karena kesuksesan tersebut bisa mengubah persepsi dan corak relasi suami-istri. Tanpa disadari oleh para suami, mereka telah memandang buruk diri sendiri saat sang istri lebih unggul dalam karir, padahal mereka tidak sedang berkompetisi dengan istri (Kompasiana, 2015).

Kultur yang menghasilkan pola pikir yang diterima dari masa ke masa oleh masyarakat di Indonesia cenderung memandang institusi pernikahan secara konvensional. Terdapat perangkat peran spesifik yang telah diterima begitu adanya (taken for granted) yang disandang secara khas oleh suami dan istri dalam rumah tangga. Banyak kalangan masyarakat, khususnya orang tua yang hidup pada masa beberapa dekade sebelum masa kini, yang memandang laki-laki sebagai suami berperan sebagai pencari nafkah utama dalam keluarga, sementara istri mengelola urusan domestik rumah tangga. Pandangan semacam ini kemudian turut berkontribusi membentuk gambaran kehidupan rumah tangga yang ideal pasangan suami-istri di zaman sekarang. Hal ini karena pada umumnya, versi ideal dari hubungan pernikahan orang tua adalah gambaran yang paling dekat untuk ditiru, berikut dengan peran-peran di dalamnya. Disamping itu, apa yang diperoleh melalui tradisi, agama, dan pandangan teman dekat mengenai bagaimana individu berperilaku dalam keluarga juga dapat turut membentuk ekspektasi peran individu dalam kehidupan rumah tangga (Beebe dan Beebe, 1986: 387).

Salah satu tolok ukur terbaik untuk memprediksikan kepuasan dalam pernikahan dan kehidupan berkeluarga adalah derajat kesesuaian ekspektasi peran anggota keluarga satu sama lain (Beebe dan Beebe, 1986: 387). Pada titik inilah komunikasi menjadi hal yang krusial dalam pernikahan, terlebih saat kita berbicara mengenai makna ekspektasi peran di dalamnya. Dalam menjalani peran dan mewujudkan ekspektasi peran di kehidupan berkeluarga, komunikasi menjadi alat utama sekaligus sebagai hal terpenting dalam menentukan kualitas kehidupan berkeluarga.

Suatu tim peneliti menemukan bahwa $86 \%$ keluarga yang mengalami kesulitan dan tekanan dalam kehidupan berkeluarga menyatakan bahwa komunikasi merupakan kunci dari sumber permasalahan yang dihadapi. Secara berurutan, presentase kategori permasalahan tersebut mulai dari yang tertinggi adalah komunikasi (86.6\%), anak (45.7\%), seks (43.7\%), keuangan (37.0\%), waktu luang (32.6\%), keluarga besar(28.4\%), ketidaksetiaan $(25.6 \%)$, perawatan rumah $(16.7 \%)$, kekerasan fisik (15.6\%), dan permasalahan lain (8.0\%) (Beck \& Jones dalam Beebe, 1986). Data ini menunjukkan bahwa komunikasi merupakan hal yang sangat penting dalam kehidupan berkeluarga yang di dalamnya berlangsung komunikasi yang bersifat transaksional.

Pengalaman komunikasi keluarga yang dilakukan melalui komunikasi transaksional melibatkan pertukaran persepsi hingga ekspektasi antar anggota keluarga yang kemudian terwujud dalam perilaku yang ditampilkan individu. Komunikasi dalam perspektif transaksional menelaah bagaimana individu menafsirkan perilaku mitra komunikasinya, secara verbal maupun nonverbal(Mulyana dalam Heryadi \& Silvana, 2013: 96). Ekspektasi mengenai peran dan hubungan dalam pernikahan ini membentuk perilaku dalam berinteraksi dan komunikasi pasangan suami-istri, orang tua dan anak, maupun dengan pihak orang tua suami/istri. Oleh karena itu, bagaimana ekspektasi peran ini dimaknai, dikomunikasikan, dan dikelola, menjadi suatu hal yang penting untuk menciptakan kesesuaian antara ekspektasi dan perilaku yang ditampilkan.

Kesesuaian antara ekspektasi peran individu dan perilaku yang ditampilkan individu lainnya sebagai sesama anggota keluarga akan mendorong terbentuknya hubungan pernikahan yang berkualitas dan kehidupan berkeluarga yang harmonis (Beebe dan Beebe, 1986: 387). Analisis mengenai pengalaman komunikasi yang dibentuk dari makna ekspektasi peran, baik antara istri terhadap suami dan anaknya, dan sebaliknya, menjadi hal yang penting khususnya dalam keluarga dengan istri yang memiliki jumlah pendapatan lebih besar dari suami. Hal ini karena terdapat pergeseran peran dalam kehidupan berkeluarga dengan istri yang bekerja dan memiliki jumlah pendapatan lebih besar sehingga cenderung berperan sebagai pengemban nafkah bagi keluarga.

Dalam pandangan subjektif seorang istri yang memiliki jumlah pendapatan lebih besar 
dari suami, meskipun pergeseran peran sentral sebagai pencari nafkah bagi keluarga tidak lagi dipandang tabu oleh kalangan masyarakat modern, peran dan pengalaman khas sebagai seorang istri yang berkontribusi lebih besar dalam perekonomian keluarga memiliki makna tersendiri bagi mereka. Bagaimana kemudian istri dengan jumlah pendapatan lebih besar dari suami ini secara subjektif menghayati pengalaman komunikasi keluarga dengan memaknai ekspektasi peran dalam hubungan pernikahan dan kehidupan berkeluarga; dan menjalani kondisi peran-peran yang mengalami pergeseran hingga perubahan, di tengah respon sosial yang mereka hadapi dalam kehidupan sehari-hari.

Penelitian ini mengambil pendekatan kualitatif dengan menggunakan studi fenomenologi. Peneliti akan meneliti pengalaman komunikasi para istri yang memiliki jumlah pendapatan yang lebih besar dari suami dan berperan lebih besar dalam menyokong perekonomian keluarga. Peneliti akan menganalisis bagaimana mereka memaknai ekspektasi peran dalam pernikahan yang dijalani dan motif bekerja para istri yang berpendapatan lebih besar dari suami ini. Teori interaksi simbolik digunakan untuk menganalisis bagaimana interaksi para istri yang berpendapatan lebih besar dari suami dalam pengalaman komunikasi keluarga yang berlangsung antara dirinya dengan suami, anak, dan orang tua dari pihak suami maupun orang tuanya sendiri dalam rangka mempertahankan keharmonisan hidup berkeluarga.

Konsep motif dalam fenomenologi Schutz digunakan untuk menganalisis motif bekerja para istri yang memiliki jumlah pendapatan lebih besar dari suami. Hal ini menjadi penting guna memahami apa yang sesungguhnya dirasakan dan dialami oleh subjek penelitian ini dalam menghayati pengalaman komunikasi keluarga sebagai istri yang memiliki jumlah pendapatan lebih besar dari suami dan berperan lebih besar dalam menyokong perekonomian keluarga.

Maksud dari penelitian ini adalah untuk menganalisis pengalaman komunikasi istriyang memiliki jumlah pendapatan lebih besar dari suami. Pengalaman komunikasi ini dipahami melalui analisis mengenai makna ekspektasi peran dalam pernikahan yang dijalani oleh istri yang memiliki jumlah pendapatan lebih besar dari suami. Makna tersebut khususnya terkait peran suami dan hubungan pernikahan yang dijalaninya. Pengalaman komunikasi keluarga istri yang diana-lisis juga terkait dengan komunikasi yang dilakukan dengan suami, anak, dan orang tua dengan menitikberatkan pada perannya yang lebih besar dalam menyokong perekonomian keluarga. Komunikasi keluarga tersebut dilakukan dalam rangka mempertahankan hubungan keluarga yang harmonis.

Tujuan dari dilaksanakannya penelitian ini adalah untuk menganalisis makna ekspektasi peran dalam pernikahan yang dijalani istri yang memiliki jumlah pendapatan lebih besar dari suami, menganalisis motif bekerja istri yang memiliki jumlah pendapatan lebih besar dari suami, dan menganalisis pengalaman komunikasi keluarga istri yang memiliki jumlah pendapatan lebih besar dari suami dalam rangka mempertahankan hubungan keluarga yang harmonis.

Hasil dari penelitian ini diharapkan dapat memberikan manfaat antara lain berupa manfaat teoretis maupun praktis. Secara akademis, penelitian ini diharapkan dapat memperkaya model penelitian kualitatif dalam kajian ilmu komunikasi keluarga, khususnya dalam konteks komunikasi keluarga yang terkait dengan makna ekspektasi peran individu dalam kehidupan berkeluarga dari sudut pandang fenomenologi. Selain itu, penelitian ini diharapkan dapat menghasilkan analisis dan model pengalaman komunikasi keluarga sebagai pengalaman individu dalam menampilkan perilaku tertentu sebagai cerminan dari makna ekspektasi yang dimiliki dalam kehidupan keluarga.

Kegunaan praktis dari penelitian ini adalah hasil yang berupa analisis dan model pengalaman komunikasi individu dalam proses komunikasi keluarga dimana istri memiliki jumlah pendapatan lebih besar dari suami dan berperan lebih besar dalam menyokong perekonomian keluarga. Analisis dan model tersebut dapat menjadi pedoman bagi proses komunikasi keluarga yang senantiasa berlangsung dalam kehidupan keluarga istri memiliki jumlah pendapatan lebih besar dari suami dan berperan lebih besar dalam menyokong perekonomian keluarga sebagai 
upaya untuk menjaga hubungan keluarga yang harmonis. Bagi masyarakat umum, analisis dan model pengalaman komunikasi keluarga yang merupakan hasil dari penelitian ini dapat menjadi pedoman untuk lebih memahami dan menerima kondisi keluarga istri yang berpendapatan lebih besar dari suami dan berperan lebih besar dalam menyokong perekonomian keluarga.

\section{METODE PENELITIAN}

Penelitian ini menggunakan paradigma konstruktivis sebagai akar pijakan filosofinya yang secara ontologis disebut sebagai relativisme, yaitu realitas yang di konstruksikan secara lokal dan spesifik (Denzin dan Lincoln, 2009: 135). Paradigma kostruktivis mengacu pada konstruktivisme, yakni filsafat pengetahuan yang meyakini bahwa pengetahuan manusia merupakan hasil konstruksi yang dibentuk oleh manusia itu sendiri. Menurut paradigma konstruktivis, realitas merupakan konstruksi sosial yang diciptakan oleh individu. Individu adalah manusia bebas yang melakukan hubungan satu sama lain. Individu menjadi penentu dalam dunia sosial yang dikonstruksi berdasarkan kehendaknya (Basrowi, 2002: 194). Dalam penelitian ini, paradigma konstruktivis digunakan sebagai pijakan dasar untuk menganalisis pengalaman komunikasi keluarga istri yang berpendapatan lebih besar dari suami dan berperan lebih besar dalam menyokong perekonomian keluarga, melalui makna yang diberikannya mengenai ekspektasi peran dalam pernikahan dan motif menjadi istri bekerja.

Peneliti menggunakan metode penelitian kualitatif dengan pendekatan fenomenologi untuk menggambarkan bagaimana pengalaman sadar individu-individu yang menjalani hubungan pernikahan dengan kondisi tersebut. Pengalaman ini terkait dengan makna ekspektasi peran dalam pernikahan dan terkait motif bekerja istri yang berpendapatan lebih besar dari suami. Creswell mengungkapkan bahwa tradisi fenomenologi adalah " $a$ study describes the meaning of the lived experiences for several individuals about a concepts or the phenomenon" (Cresswell, 1997: 51). Sementara itu, Littlejohn menyebutkan bahwa tradisi fenomenologi fokus pada pengalaman sadar seseorang. Individu secara aktif menginterpretasikan pengalaman mereka dan memahami kehidupan melalui pengalaman pribadi (Littlejohn, 2005: 38).

Peneliti menggunakan metode fenomenologi karena dengan metode ini peneliti dapat menganalisis komunikasi keluarga istri yang memiliki jumlah pendapatan lebih besar dari suami dan berperan lebih besar dalam menyokong perekonomian keluarga melalui makna yang diberikannya terhadap ekspektasi peran dalam pernikahan yang dijalani dengan dilandasi motif menjadi istri bekerja dalam rangka mempertahankan kehidupan keluarga yang harmonis.

\section{HASIL DAN PEMBAHASAN}

Makna ekspektasi peran dalam pernikahan istri yang berpendapatan lebih besar dari suami diawali dengan ekspektasi yang dimiliki mengenai sosok dan peran suami ideal. Ekspektasi tersebut meliputi: 1) sosok suami yang memiliki jumlah pendapatan yang lebih besar dari istri; 2) seiman dan merupakan pribadi yang sholeh; 3) berperan sebagai pemimpin keluarga, dan; 4) menjadi ayah yang dekat dengan anak-anaknya. Namun kenyataan yang dihadapi para informan penelitian ini berbeda dengan ekspektasi, yakni pendapatan yang dimiliki suami tidak lebih besar dari istri sehingga suami tidak mampu berperan lebih dalam menyokong perekonomian keluarga. Yang terjadi justru sebaliknya, para istri ini memiliki pendapatan yang lebih besar dari suami dan mereka berperan lebih dalam menyokong perekonomian keluarga.

Menghadapi kenyataan ini, para istriyang berpendapatan lebih besar menghayati kembali motif penerimaan terhadap pasangan di masa pra-nikah yang membuat mereka akhirnya memutuskan untuk hidup bersama dalam pernikahan meski dengan kondisi ekspektasi mengenai peran suami yang ideal tidak terpenuhi. Motif tersebut adalah kesediaan pasangan untuk memenuhi syarat selama masa hubungan pra-nikah, karakter pasangan yang bersikap sopan dan menghormati orang tua, rasa cinta, sifat gigih yang dimiliki oleh pasangan, serta optimisme mengenai masa depan yang lebih baik bersama pasangan. 
Motif-motif ini mengompensasi ekspektasi mengenai peran suami yang ideal sehingga menumbuhkan penerimaan oleh para istri yang berpendapatan lebih besar dari suami.

Dalam memaknai ekspektasi mengenai sosok dan peran suami ideal yang berbeda dengan kenyataan yang dihadapi, para informan meyakini bahwa sebagai wanita beriman, mereka harus tetap berbakti pada suami dan menghargainya selaku imam keluarga. Informan juga tetap menerima suami dan berusaha lebih baik dalam menyokong perekonomian keluarga bersama suami. Hingga saat ini bertahan dalam pernikahan yang dijalani dengan kesenjangan antara ekspektasi dan kenyataan yang dihadapi, penerimaan para istri yang berpendapatan lebih besar dari suami ini juga dibentuk oleh makna yang berikan mengenai ekspektasi peran-peran dalam rumah tangga dan relasi suami-istri bersama pasangannya.

Bagi para istri ini, peran mereka yang lebih besar dalam menyokong perekonomian keluarga merupakan bentuk kerja sama dalam kehidupan rumah tangga. Perilaku suami yang turut membantu mengerjakan pekerjaan domestik rumah tangga juga membentuk makna bahwa dalam menjalankan peranperan dalam rumah tangga, suami-istri saling membantu dan mengisi. Perilaku ini dinilai oleh istri sebagai wujud kompensasi atas 'pertukaran peran' yang dijalani suami-istri, dimana sebagai istri, ia berperan lebih besar dalam menyokong perekonomian keluarga. Dalam relasi suami-istri yang dijalani, istri yang berpendapatan lebih besar dari suami ini memaknai ekspektasinya bahwa suami dan istri bersama-sama bekerja dan berwirausaha untuk mencukupi kebutuhan keluarga, meski dengan kondisi suami tidak memperoleh pendapatan yang lebih besar. Relasi yang didasari kerja sama membuat pasangan suami-istri ini juga mampu menyepakati solusi bersama atas konflik yang dihadapi, khususnya konflik yang terkait dengan hubungan orang tua.

Makna ekspektasi mengenai sosok dan peran suami dalam pernikahan istri yang berpendapatan lebih besar dari suami juga terkait dengan sikap terhadap respon lingkungan terdekat. Respon dari lingkungan terdekat menimbulkan makna yang semakin berarti mengenai ekspektasi sosok dan peran suami dan sikap dalam pernikahan yang telah dijalani. Pengalaman yang sama yang dialami oleh teman dekat di tempat bekerja dijadikan sebagai inspirasi dan referensi dalam menjalani pernikahan dengan kondisi kesenjangan antara ekspektasi dan kenyataan yang dihadapi. Sementara itu, respon yang dinilai kurang mendukung, justru dijadikan sebagai medium untuk meneguhkan penerimaan berdasarkan nilai-nilai keimanan bahwa sebagai istri yang baik, sudah sepatutnya menghormati suami meski suami tidak berperan lebih besar dalam menyokong perekonomian keluarga. Respon yang dinilai sangat tidak mendukung disikapi oleh istri yang berpendapatan lebih besar dari suami secara tegas dengan menjaga martabat suami di hadapan pihak yang terindikasi merendahkan martabat suami.

Kelima dimensi yang membentuk makna ekspektasi peran yang dimiliki oleh istri yang berpendapatan lebih besar dari suami seperti yang telah dijelaskan di atas, menciptakan keharmonisan dalam pernikahan yang dijalani. Keharmonisan ini membuat para istri yang berpendapatan lebih besar dari suami dan berperan lebih besar dalam menyokong perekonomian keluarga mampu bertahan dalam pernikahannya. Namun demikian, terdapat seorang informan yang bertahan dalam pernikahan yang dikondisikan tetap harmonis meski terjadi konflik di dalamnya yang dipicu oleh kesenjangan antara ekspektasi mengenai sosok dan peran suami dengan kenyataan yang dihadapi.

Informan yang tetap bertahan dalam pernikahan yang dikondisikan harmonis akhirnya memaknai ekspektasi mengenai sosok dan peran suaminya sebagai sesuatu yang harus tetap diterima dengan pertimbangan keutuhan keluarga demi masa depan anak, meski suaminya sendiri bahkan tidak memenuhi ekspektasinya sebagai sosok ayah yang dekat dengan anak-anaknya. Informan ini menyadari bahwa sedari awal, motifnya menerima pasangan di masa pra-nikah hingga akhirnya memutuskan untuk menikah dengan suaminya sampai saat ini, didorong oleh hal yang bersifat negatif, yakni pembuktian diri atas dendam masa lalu, bukan cenderung dilandasi perasaan cinta.

Peran suami yang nampak dari perilaku yang ditampilkan dinilai informan tidak dapat 
mengompensasi kesenjangan antara ekspektasi mengenai sosok dan peran suami ideal dengan kenyataan yang dihadapi. Ini terjadi karena minimnya kesadaran suami untuk berperan dan bekerja sama dalam melaksanakan peranperan dalam rumah tangga. Dalam relasi pasangan suami-istri pun, upaya suami dinilai minim untuk memelihara hubungan yang baik dan komunikasi yang efektif dengan istrinya yang telah rela bekerja keras demi menyokong perekonomian keluarga. Kondisi seperti ini membentuk makna ekspektasi yang dimiliki oleh istri mengenai sosok dan peran suami, yang bersifat negatif dan membuat frustrasi dalam pernikahan yang dijalani. Respon dari sahabat yang berada dalam lingkungan terdekat membangkitkan kesadaran mengenai pemahaman yang keliru mengenai peran-peran dalam rumah tangga yang selama ini cenderung dibebankan pada dirinya secara sepihak.

Relasi pasangan suami-istri yang terjalin dalam pernikahan istri yang berpendapatan lebih besar dari suami berlangsung dinamika yang membentuk makna ekspektasi peran yang dimiliki oleh para informan penelitian ini. Pasangan suami-istri, khususnya istri sebagai informan penelitian ini, mendefinisikan kembali hakikat pernikahan yang dijalaninya, termasuk peran-peran di dalamnya, alih-alih melihat pernikahan sebagai suatu ikatan formal yang memuat peran-peran spesifik yang secara khas dan saklek dilakukan oleh suami/istri. Pendefinisian kembali dilakukan ketika mereka telah memutuskan untuk menikah dengan sosok laki-laki yang tidak memenuhi ekspektasi mengenai peran suami ideal dengan dilandasi ikatan psikologis dan emosional di antara keduanya. Ikatan ini menimbulkan kelekatan dalam relasi pasangan suami-istri yang didasari oleh kesadaran akan pentingnya pasangan bagi satu sama lain. Kelekatan di antara keduanya kemudian menumbuhkan pemakluman, menciptakan ruang maaf, hingga menimbulkan penerimaan atas kondisi pasangan dalam pernikahan yang telah dijalani bersama.

Bagi informan penelitian ini, kelekatan dengan pasangan membuat mereka bersedia menegosiasikan berbagai ekspektasi peran yang ideal dalam pernikahan. Di sisi lain, suami juga menampilkan perilaku yang mengompensasi kesenjangan antara ekspektasi peran yang ideal mengenai dirinya dengan kenyataan yang dihadapi oleh istri. Perilaku yang ditampilkan dan dinilai oleh pasangan satu sama lain dalam relasi pasangan suamiistri yang meliputi kuasa di antara pasangan, proses pengambilan keputusan, konflik, dan keintiman di antara keduanya juga memiliki makna tersendiri bagi istri yang berpendapatan lebih besar dari suami dalam menegosiasikan ekspektasinya mengenai sosok dan peran suami ideal. Negosiasi ekspektasi oleh istri dan perilaku yang mencerminkan kompensasi peran suami inilah yang membuat istri yang berpendapatan lebih besar ini berlapang dada dalam berperan lebih besar menyokong perekonomian keluarga dan bertahan dalam pernikahan yang harmonis.

Keharmonisan empat aspek dalam relasi pasangan suami-istri yakni kuasa di antara pasangan, proses pengambilan keputusan, konflik, dan keintiman di antara keduanya, dan perilaku suami yang mencerminkan kesadaran untuk tetap bertanggung jawab mengemban peran-peran dalam rumah tangga sangat terkait dengan makna ekspektasi peran dalam pernikahan istri yang berpendapatan lebih besar dari suami dan lebih berperan dalam menyokong perekonomian keluarga. Jalinan keempat aspek tersebut dalam suasana yang kondusif mendorong para istri ini untuk menegosiasikan ekspektasinya hingga bersedia menerima kondisi suami dalam pernikahan yang dijalani. Berikut merupakan model yang menggambarkan realitas tersebut:

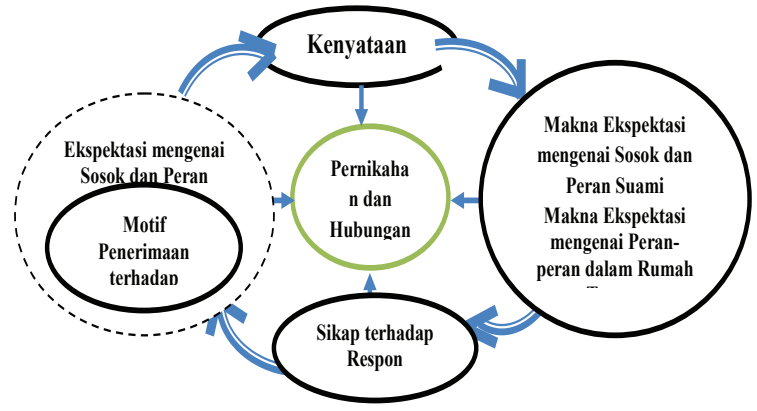

Gambar 1. Model Realitas Makna Ekspektasi Peran dalam Pernikahan Istri yang Berpendapatan Lebih Besar dari Suami Sumber: Pengumpulan Data, Agustus-Oktober 2015

Berikut merupakan model yang dirancang dari hasil elaborasi penulis terhadap hasil penelitian dan pengumpulan data dengan teori terkait dan konsep yang relevan dengan makna ekspektasi peran dalam pernikahan istri yang berpendapatan lebih besar dari suami: 


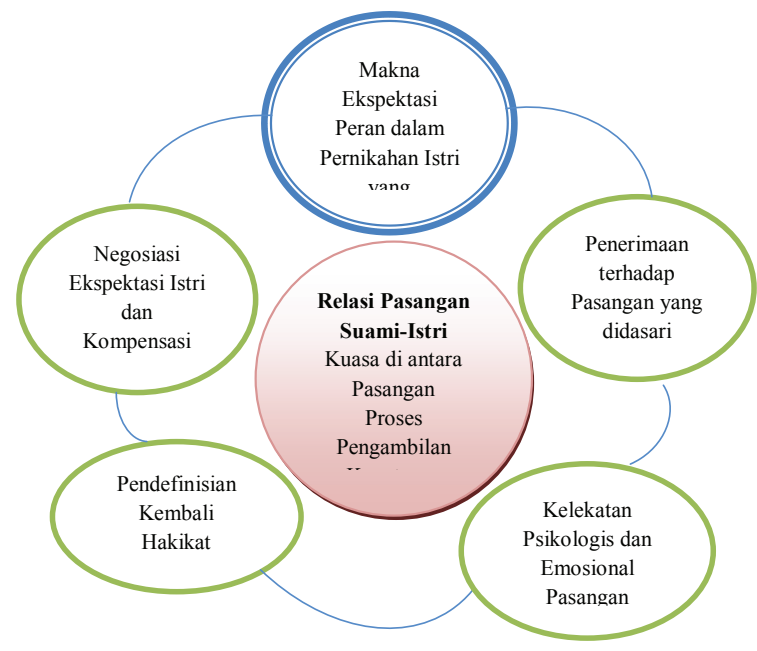

Gambar 2. Model Elaborasi Makna Ekspektasi Peran dalam Pernikahan Istri yang Berpendapatan Lebih Besar dari Suami

Sumber: Pengumpulan Data, Agustus-Oktober 2015

Motif bekerja istri yang berpendapatan lebih besar dari suami terkait dengan berbagai makna yang mereka berikan mengenai: 1) peran diri sebagai istri yang berpendapatan lebih besar dari suami dan berperan lebih besar dalam menyokong perekonomian keluarga; 2) perilaku suami; 3) pekerjaan yang dijalani, dan 4) respon/kondisi lingkungan sekitar. Adapun motif bekerja kelima orang informan penelitian ini adalah untuk memiliki penghasilan sendiri dan menjadi istri yang mandiri secara finansial ( $\mathrm{Li}$ \{nama samaran\}), untuk taraf hidup keluarga yang lebih baik (Nia), karena berperan sebagai penyokong ekonomi keluarga (Sury), untuk menyokong perekonomian keluarga (Dalis), dan untuk memanfaatkan ilmu yang diperoleh hingga jenjang pendidikan S2 (Iza).

Motif bekerja yang dimiliki oleh para istri yang berpendapatan lebih besar dari suami tersebut membentuk makna tersendiri mengenai peran diri sebagai sosok yang lebih berperan dalam menyokong perekonomian keluarga. Makna peran diri tersebut yaitu: tidak merasa bangga, berusaha menekan perasaan terbebani; menekan ego, menyadari bahwa kepatuhan terhadap suami adalah keharusan seorang istri; mencoba menerima dengan ikhlas sebagai hukuman atas kesalahan di masa lalu, dan; senantiasa bersyukur dan menghindari pikiran negatif mengenai kondisi pernikahan yang dijalani.

Makna peran diri di atas terkait dengan makna yang diberikan para istri mengenai perilaku suami dalam menjalankan peranperan dalam kehidupan keluarga. Perilakuperilaku tersebut meliputi: kesadaran untuk tetap bekerja dan memperoleh pendapatan; komunikasi yang baik, perhatian, dan kasih sayang kepada istri; kesadaran dan tanggung jawab untuk bekerja sama dengan istri dalam menyokong perekonomian keluarga, dan konsistensi dalam menjalani kesepakatan bahwa suami dan istri harus bekerja. Perilakuperilaku ini dinilai para informan mendukung pekerjaan yang dijalaninya sehingga mereka dapat memaknai pekerjaan sebagai sebagai sesuatu yang dinikmati dan disyukuri, sarana untuk memanfaatkan ilmu yang sudah diperoleh, disamping sebagai sarana untuk memiliki kemandirian finansial dan suatu ke harusan untuk menyokong perekonomian keluarga besar.

Kondisi dimana ekspektasi sosok dan peran suami ideal sebagaimana yang diharapkan tidak terwujud di kenyataan, membuat para istri ini harus tetap bekerja dan berperan lebih besar dalam menyokong perekonomian keluarga. Namun demikian, mereka tetap bertahan menjalani pekerjaan dan peran dirinya. Penerimaan ini tidak terlepas dari sikap yang timbul sebagai penghayatan terhadap makna mengenai respon/kondisi lingkungan sekitar istri yang berpendapatan lebih besar dari suami, yakni: merefleksikan kisah dan pengalaman pernikahan orang terdekat dengan kondisi sejenis; merujuk pada pernikahan kedua orang tua; berusaha agar rumah tangga tidak dipenuhi konflik, dan; meneguhkan penerimaan sebagai istri yang berperan lebih besar dalam menyokong perekonomian keluarga.

Terdapat empat aspek makna yang terkait dengan motif bekerja istri yang berpendapatan lebih besar dari suami. Realitas intersubjektif pernikahan para informan penelitian ini bersama suaminya membentuk makna mengenai pekerjaan yang dijalani dan makna mengenai perilaku suami. Perilaku suami yang tidak berpendapatan lebih besar dari dirinya, namun tetap memiliki kesadaran, tanggung jawab, dan kerja sama dalam menjalankan peran-peran dalam kehidupan keluarga, membuat para istri yang berperan lebih besar dalam menyokong perekonomian keluarga ini memaknai pekerjaannya sebagai 
sesuatu yang dinikmati. Sebaliknya, perilaku suami yang dinilai tidak memenuhi ekspektasi istri, membuat istri merasa terbebani dengan perannya sebagai istri bekerja dan berperan lebih dalam menyokong perekonomian keluarga.

Dalam memaknai peran diri sebagai istri bekerja dan berperan lebih besar dalam menyokong perekonomian keluarga, nilai-nilai yang dipahami dan diyakini mengenai lembaga pernikahan membuat para informan penelitian ini tetap menghormati suami selaku kepala keluarga dan sosok yang dipandang sebagai pemimpin dalam keluarga. Kecenderungan untuk merasa ego atau bangga terhadap diri sendiri berusaha untuk ditekan oleh para istri ini. Mereka berupaya untuk ikhlas menerima dan bersyukur dalam menjalani kondisi yang dihadapi demi keharmonisan pernikahan.

Selanjutnya, motif bekerja istri yang berpendapatan lebih besar dari suami juga terkait dengan makna mengenai respon/kondisi lingkungan sekitar. Interaksi yang dilakukan para informan dengan orang-orang yang dinilai mendukung konsonansi kognitif mengenai kondisi pernikahan yang dijalani membuat mereka memaknai kembali peran dirinya sebagai istri bekerja yang berpendapatan lebih besar dari suami dan lebih berperan dalam menyokong perekonomian keluarga. Makna yang kemudian dipahami dan diyakini adalah makna yang bersifat konstruktif dalam meneguhkan penerimaan mereka terhadap kondisi pernikahan dan mempertahankan pernikahan yang harmonis. Berikut merupakan model yang menggambarkan realitas mengenai motif bekerja istri yang berpendapatan lebih besar dari suami:

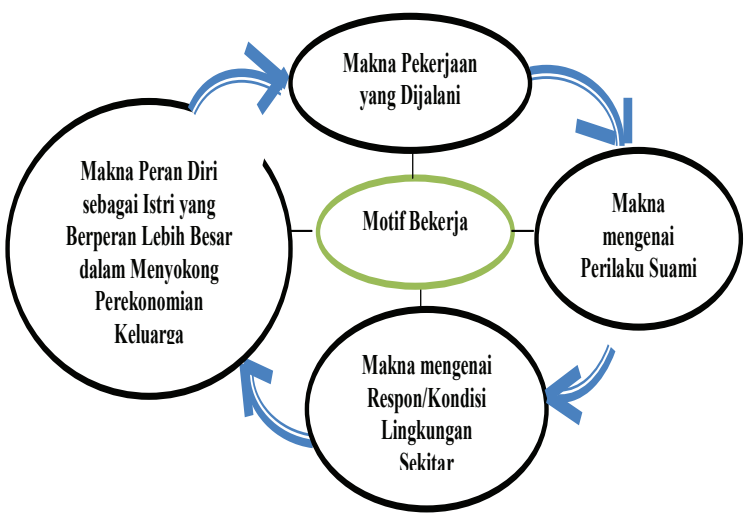

Gambar 3. Model Realitas Motif Bekerja Istri yang Berpendapatan Lebih Besar dari Suami Sumber: Pengumpulan Data, Agustus-Oktober 2015
Selanjutnya, berikut merupakan model yang dirancang dari hasil elaborasi penulis terhadap hasil penelitian dan pengumpulan data dengan teori terkait dan konsep yang relevan dengan makna motif bekerja istri yang berpendapatan lebih besar dari suami dan berbagai aspek yang terkait dengannya yang juga dimaknai oleh para informan penelitian ini:

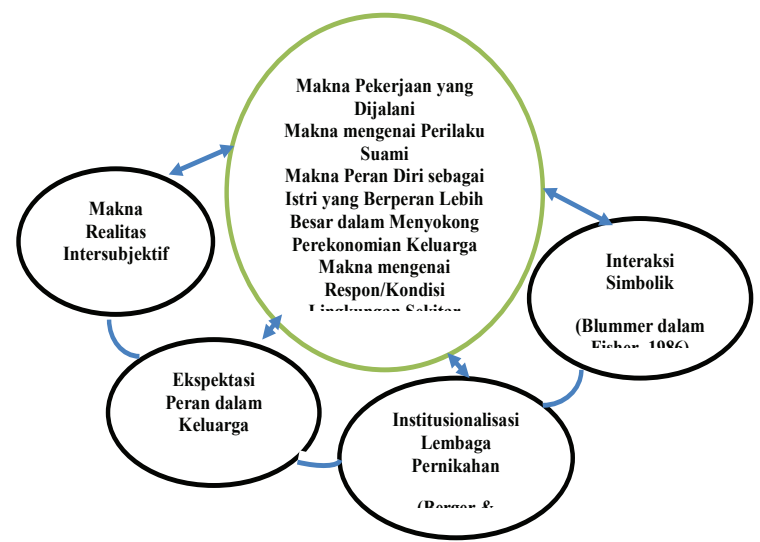

Gambar 4. Model Elaborasi Motif Bekerja Istri yang Berpendapatan Lebih Besar dari Suami Sumber: Pengumpulan Data, Agustus-Oktober 2015, Tinjauan Teoretis dan Konseptual

Pengalaman komunikasi keluarga istri yang berpendapatan lebih besar dari suami berlangsung dalam interaksi dengan suami, anak, dan orang tua dari pihak suami maupun istri. Adapun makna keluarga harmonis yang dimiliki oleh para informan penelitian ini merujuk dari pengalaman khas yang mereka alami dan rasakan dalam kehidupan keluarga sebagai istri yang berpendapatan lebih besar dari suami dan berperan lebih besar dalam menyokong perekonomian keluarga. Keluarga harmonis dimaknai sebagai keluarga yang utuh dalam kebersamaan yang terjaga (Li), saling mengerti sesama anggota keluarga (Nia), suami dan istri mengerti hak dan kewajiban masing-masing dan menjalankannya dengan penuh tanggung jawab (Sury). Makna keluarga harmonis juga berarti saling mengerti, saling menyayangi sesama anggota keluarga, terutama kepada orang tua (Dalis), dan saling percaya, rukun, dan damai dalam kehidupan berkeluarga (Iza).

Untuk mewujudkan dan mempertahankan hubungan keluarga yang harmonis sebagaimana yang dimaknai oleh masingmasing informan, mereka menjaga keharmonisan relasi suami-istri dengan cara: memahami karakter dan menerima kondisi 
pasangan; meredam potensi konflik suamiistri; mensyukuri keadaan dan senantiasa berpikir positif; menjaga keterbukaan dan kerja sama pengelolaan keuangan rumah tangga antara suami-istri, dan; melibatkan suami untuk sama-sama berperan dalam menyokong perekonomian keluarga.

Dengan anak-anaknya, para istri yang berpendapatan lebih besar dan berperan lebih besar dalam menyokong perekonomian keluarga juga menjaga kedekatan dengan anak-anaknya sebagai bagian dari upaya mempertahankan hubungan keluarga yang harmonis. Mereka menjadi ibu yang bisa diandalkan dalam memenuhi kebutuhan materi dan afeksi anak; menggunakan otoritas secara proporsional sebagai ibu yang berpendapatan lebih besar dari ayah anak-anaknya, serta; mendidik anak untuk cermat dan tekun dalam usaha memenuhi keinginan yang membutuhkan biaya yang besar.

Selanjutnya, upaya menjaga keharmonisan dengan orang tua suami/istri dilakukan para informan penelitian ini dengan cara: menghindari potensi konflik yang bersumber dari kesalahpahaman mengenai kesibukan sebagai istri yang bekerja di luar rumah (Li), berusaha selalu hadir dan ikut serta dalam acara keluarga besar (Nia), mengunjungi mertua dan memberikan buah tangan (Sury), bersikap adil dalam memberi sebagian dari pendapatan yang diperoleh kepada orang tua suami/istri (Dalis), dan meluruskan kesalahpahaman akibat praduga mengenai ego istri yang berpendapatan lebih besar dari suami (Iza).

Merujuk dari perilaku komunikasi para istri sebagai informan penelitian ini dengan keluarganya, adaptabilitas, kohesifitas, dan proses komunikasi yang berlangsung di dalamnya berada pada titik yang seimbang. Tiga dimensi dasar tersebut, yakni adaptabilitas, kohesifitas, dan komunikasi menjelaskan dinamika fungsi efektif dan disfungsi di dalam komunikasi keluarga sebagaimana yang dijelaskan dalam Model Sirkumpleks Interaksi Keluarga (Circumplex Model of Family Interaction). Adaptabilitas merupakan kemampuan keluarga untuk memodifikasi dan merespon perubahan dalam kekuatan struktur dan peran-peran yang ada di dalamnya. Lebih jauh, dimensi adaptabilitas yang berlangsung pada titik yang seimbang ini juga terdapat dalam kehidupan keluarga yang dijalani oleh para istri sebagai informan penelitian ini. Keseimbangan tersebut dapat dicapai karena relasi pasangan suami-istri yang terjalin dan bertahan sampai saat ini didukung oleh kemampuan mereka untuk menyesuaikan diri dengan perubahan peran dalam struktur di institusi keluarga; istri berperan sebagai pihak yang berperan lebih besar dalam menafkahi keluarga, dan suami bersedia untuk melaksanakan tugas-tugas domestik rumah tangga.

Struktur keluarga yang menentukan peranperan khas anggota di dalamnya sebagai-mana kultur dan cara pandang konvensional mengenai kehidupan keluarga di Indonesia, dimodifikasi oleh pasangan suami-istri informan penelitian ini. Mereka melakukan modifikasi/perubahan terhadap peran spesifik suami/istri, sambil tetap berusaha mengemban perankhas seorang suami/ istri dalam kehidupan rumah tangga, yakni istri tetap ambil bagian dalam melaksanakan tugastugas domestik rumah tangga, sedangkan suami tetap bekerja dan memperoleh pendapatan untuk menafkahi keluarga meskipun jumlahnya tidak lebih besar dari yang mampu diberikan oleh istri. Ini mencerminkan peran-peran yang ada dalam keluarga pasangan suami-istri ini berlangsung secara dinamis dibandingkan peranperan dalam keluarga tipe pasangan tradisional yang cenderung mengedepankan stabilitas berdasarkan fungsi stuktur konvensional.

Dimensi yang kedua adalah kohesi, yang merujukpadaikatan emosidanrasakebersamaan yang dimiliki keluarga. Urutan dimensi kohesi dalam model ini dimulai dari sangat erat atau terperangkap, sampai terpisah. Kohesifitas dalam keluarga pasangan suami-istri dengan istri yang berpendapatan lebih besar ini juga cenderung berada pada titik yang seimbang. Tipe pasangan mandiri yang merupakan karakteristik pasangan informan-informan dalam penelitian ini membuat suami/istri memiliki otonomi yang tinggi, sehingga ikatan emosi dan kebersamaan yang terjalin dalam keluarga berada pada kadar yang proporsional. Waktu yang mereka miliki bersama dengan lingkungan terdekat lainnya di luar keluarga, seperti orang tua dan teman-teman di lingkungan kerja, membuat kebersaman individu pasangan suami-istri ini membagi ruang kedekatan yang dimiliki. Kemandirian finansial dari para istri dan kerelaannya untuk berperan lebih besar dalam menafkahi keluarga; serta kesediaan suami untuk bertenggang rasa 
dengan melaksanakan tugas-tugas domestik rumah tangga juga turut menumbuhkan kohesifitas yang seimbang karena peran-peran yang berlaku lebih fleksibel di antara keduanya.

Dimensi yang ketiga dalam model sirkumpleks interaksi keluarga, dan merupakan elemen paling krusial adalah komunikasi. Melalui komunikasi, keluarga mampu ber-adaptasi untuk mengubah dan memelihara hubungan terikat atau terpisah. Komunikasi menentukan apakah sebuah keluarga bersifat kohesif dan atau mampu beradaptasi. Komunikasi menjaga kelangsungan sistem keluarga. Adapun adaptabilitas dan kohesifitas yang seimbang (sedang) mencerminkan keterampilan komunikasi yang memadai dari pasangan suami-istri yang menjadi informan dalam penelitian ini. Mereka terbiasa dengan perubahan dan mampu mengelolanya dengan baik melalui komunikasi yang efektif. Dinamisasi peran dalam keluarga pasangan suami-istri ini membuat kohesifitas di antara keduanya berada pada kadar yang sedang.

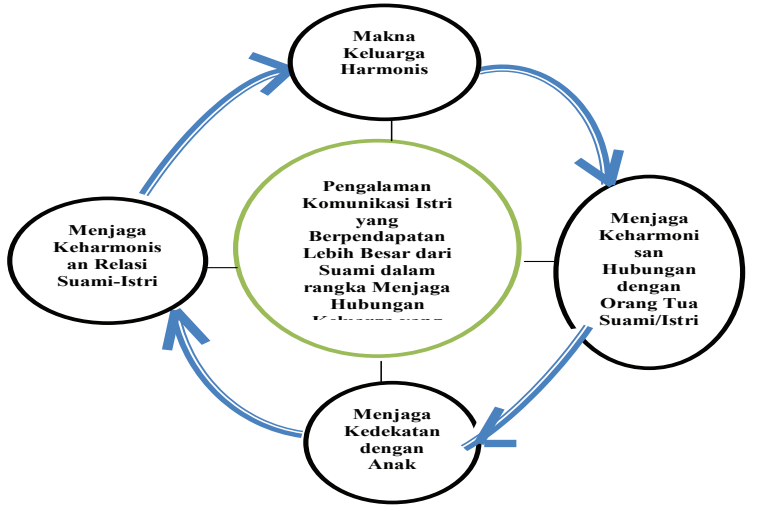

Gambar 5. Model Realitas Pengalaman Komunikasi Istri yang Berpendapatan Lebih Besar dari Suami dalam rangka Menjaga Hubungan Keluarga yang Harmonis

Sumber: Pengumpulan Data, Agustus-Oktober 2015

Adaptabilitas dan kohesifitas ini juga terkait hubungan dengan orang tua. Pola pikir orang tua yang cenderung merujuk pada struktur dan historisitas yang kaku mengenai peran-peran dalam rumah tangga, tak jarang menimbulkan praduga yang keliru mengenai relasi pasangan suami-istri dengan istri yang berpendapatan lebih besar. Oleh karena itu, para informan dalam penelitian ini berusaha untuk menjalin komunikasi dan menjaga hubungan baik dengan orang tua, khusunya orang tua dari pihak suami (mertua). Sebagai upaya untuk menjaga keharmonisan hubungan dengan pihak keluarga suami, istri-istri ini berusaha untuk menampilkan perilaku yang memenuhi ekspektasi mertua, khususnya mertua perempuan, mengenai peran seorang menantu yang ideal.

Berikut merupakan model yang dirancang dari hasil elaborasi penulis terhadap hasil penelitian dan pengumpulan data dengan teori terkait dan konsep yang relevan dengan pengalaman komunikasi istri yang berpendapatan lebih besar dari suami dalam rangka menjaga hubungan keluarga yang harmonis:

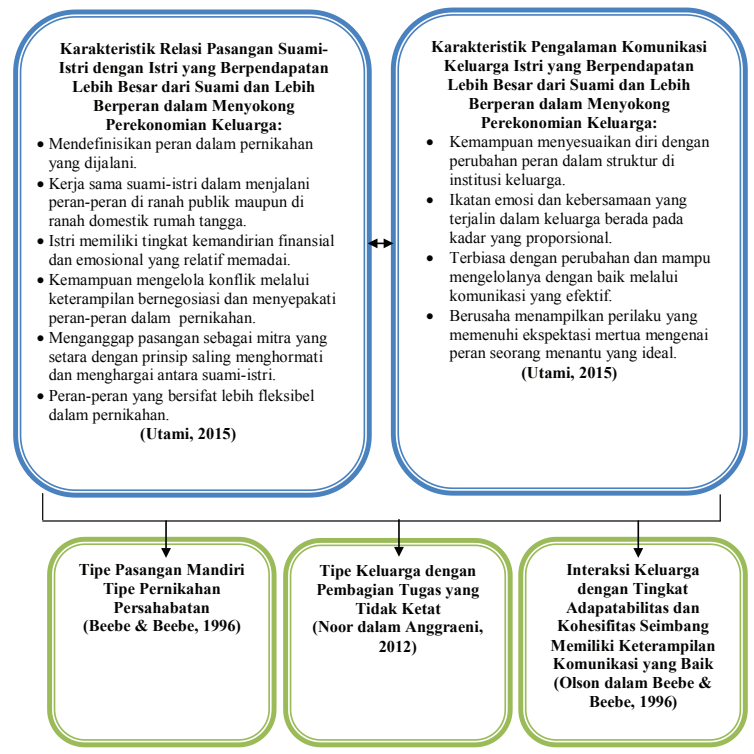

Gambar 6. Model Elaborasi Pengalaman

Komunikasi Istri yang Berpendapatan Lebih Besar dari Suami dalam rangka Menjaga Hubungan Keluarga yang Harmonis Sumber: Pengumpulan Data, Agustus-Oktober 2015

\section{SIMPULAN}

Terdapat enam dimensi yang terkait dengan makna ekspektasi peran dalam pernikahan istri yang berpendapatan lebih besar dari suami. Enam dimensi ini berlangsung dalam situasi interaksi istri yang berpendapatan lebih besar dari suami dengan suami, lingkungan terdekat (keluarga dan teman), maupun dengan dirinya sendiri. Enam dimensi tersebut adalah: 1) ekspektasi mengenai sosok dan peran suami ideal; 2) makna ekspektasi mengenai sosok dan peran suami; 3) makna ekspektasi mengenai peran-peran dalam rumah tangga; 4) makna ekspektasi istri mengenai relasi suami-istri; 5) motif penerimaan terhadap pasangan di masa pra-nikah, dan; 6) penyikapan terhadap respons lingkungan terdekat. Keenam dimensi ini menjelasakan hal-hal yang menyebabkan 
para istri yang berpendapatan lebih besar dari suami ini tetap bertahan dalam pernikahannya meski dengan kondisi ekspektasi yang mereka miliki mengenai sosok dan peran suami tidak terpenuhi dalam pernikahan yang dijalani. Hal ini karena mereka memaknai kembali ekspektasi tersebut dengan merefleksikan pengalaman yang mereka alami di kenyataan, yakni: suami yang tetap berusaha untuk bekerja dan memberi nafkah bagi keluarga; kebaikan-kebaikan yang ada pada diri suami; kesadaran dari suami untuk memenuhi ekspektasi istri pada sisi yang ia mampu dengan tetap mengemban tanggung jawabnya selaku kepala keluarga, suami yang penuh perhatian dan kasih sayang, dan ayah yang dekat dengan anak-anak, serta; kesediaan suami untuk mengerjakan pekerjaan domestik rumah tangga sebagai bentuk kompensasi atas kerelaan istri 'bertukar peran' dengan dirinya. Adapun informan yang tetap bertahan dalam pernikahannya meskipun terdapat konflik di dalamnya karena mempertimbangkan kebaikan dan masa depan anak-anak dalam keluarga yang tetap utuh.

Terdapat dua jenis motif yang mendorong para informan dalam penelitian ini untuk menjadi istri bekerja. Dua jenis motif tersebut merujuk dari konsep motif yang dikemukakan oleh Alfred Schutz dalam perspektif teori fenomenologinya, yakni dan motif untuk (in order to motives) dan motif karena (because motives). Motif-motif tersebut adalah: untuk memanfaatkan ilmu yang diperoleh sampai jenjang pendidikan tinggi; untuk taraf hidup keluarga yang lebih baik; untuk memiliki kemandirian finansial; karena pengalaman keterbatasan perekonomian keluarga di masa lalu; karena berperan menyokong perekonomian keluarga, dan; karena merupakan kesepakatan dengan suami. Dari pekerjaan yang dijalani oleh para informan ini, mereka memperoleh jumlah pendapatan yang lebih besar dari suaminya hingga dua kali lipat (suami berpendapatan kurang dari 50\% dari jumlah pendapatan istri). Dari motif-motif ini, diketahui makna pekerjaan yang dijalani oleh para istri yang berpendapatan lebih besar dari suami ini, yakni sebagai sesuatu yang dinikmati dan disyukuri, sekaligus sebagai sarana untuk memberi nafkah bagi keluarga. Terdapat satu informan yang menjalani pekerjaan dengan berat dan penuh tekanan akibat konflik yang muncul dalam relasi pasangan suami-istri yang dijalaninya. Para istri yang berpendapatan lebih besar dari suami ini memaknai peran dirinya sebagai istri yang tetap harus menghormati suami sebagai sosok pemimpin dalam keluarga; mereka tidak merasa bangga atas peran diri yang berperan lebih besar dalam menyokong perekonomian keluarga, menekan ego sebagai seorang perempuan, serta tidak ingin melawan atau membangkang kepada suaminya. Bahkan, para informan ini berusaha terus memberi dukungan kepada suami agar tidak merasa rendah diri, dan senantiasa berusaha dan bekerja untuk mencapai tingkat pendapatan yang lebih baik.

Pengalaman komunikasi keluarga istri yang berpendapatan lebih besar dari suami dalam rangka mempertahankan hubungan keluarga yang harmonis meliputi komunikasi yang dilakukan dengan suami, anak, dan orang tua. Dengan suaminya, para informan ini berusaha untuk menjaga keharmonisan relasi suamiistri dalam komunikasi yang terjalin di antara keduanya dengan cara memahami karakter dan menerima kondisi suami; meredam potensi konflik yang dipicu oleh persoalan finansial; mensyukuri keadaan dan berusaha tetap berpikir positif; saling terbuka dan bekerjasama dalam mengelola keuangan rumah tangga, dan; melibatkan suami untuk sama-sama berperan dalam menyokong perekonomian keluarga. Dengan anak, sebagai ibu, meskipun memiliki pendapatan yang lebih besar dari ayah anakanaknya, para informan penelitian ini menggunakan otoritasnya secara proporsional. Dengan otoritas yang proporsional tersebut, mereka mendidik anak untuk cermat dan tekun dalam usaha memenuhi keinginan yang membutuhkan biaya yang besar. Melalui pengalaman komunikasi keluarga sebagai istri yang berpendapatan lebih besar dari suami, para istri ini merasa menjadi ibu yang bisa diandalkan dalam memenuhi kebutuhan materi dan afeksi anak. Selanjutnya, dengan orang tua, baik orang tuanya sendiri, terlebih dengan orang tua dari pihak suami (mertua) yang rentan terhadap praduga yang keliru mengenai kondisi istri yang memiliki kesibukan bekerja di luar rumah dan berpendapatan lebih besar dari suami, para istri ini juga berusaha untuk senantiasa menjaga keharmonisan hubungan. 
Mereka menghindari potensi konflik yang bersumber dari kesalahpahaman mengenai kesibukan sebagai istri yang bekerja di luar rumah; selalu hadir dan ikut serta dalam acara keluarga besar; mengunjungi mertua dan memberikan buah tangan; adil dalam memberi sebagian dari pendapatan yang diperoleh kepada orang tua suami/istri, dan; meluruskan kesalahpahaman akibat praduga mengenai ego istri yang berpendapatan lebih besar dari suami.

Pasangan suami-istri informan dalam penelitian ini merupakan tipe pasangan mandiri. Suami/istri memiliki tingkat otonomi yang tinggi dan mendefinisikan peran-peran dalam hubungan pernikahan. Hal ini terlihat dari pernikahan yang bertahan sampai saat ini meskipun tidak mengikuti pakem-pakem peran dalam pernikahan yang bersifat tradisional/ konvensional. Peran yang didefinisikan dan dijalani oleh pasangan suami-istri informan penelitian ini adalah istri yang berpendapatan lebih besar dari suami sehingga lebih berperan dalam menyokong perekonomian keluarga, sementara suami tidak merasa enggan untuk melaksanakan tugas-tugas domestik rumah tangga. Pasangan ini tergolong tipe keluarga yang melakukan pembagian tugas dengan cair dan tidak ketat, bersifat situasional dan kondisional. Mereka memandang pasangannya sebagai mitra yang setara, dengan prinsip saling menghormati dan menghargai antara suamiistri. Oleh karena itu, pernikahan yang dijalani merupakan tipe pernikahan persahabatan. Interaksi keluarga pasangan suami-istri dengan istri yang berpendapatan lebih besar dari suami ini berlangsung pada titik seimbang dengan adaptabilitas dan kohesifitas pada tingkat yang sedang, yang mencermikan keterampilan komunikasi yang baik yang dimiliki oleh individu-individu di dalamnya. Adapun disfungsi sistem keluarga pasangan suamiistri seperti yang dialami salah satu informan penelitian ini disebabkan oleh minimnya kesadaran suami mengenai kerja sama suamiistri dalam melaksanakan tanggung jawab dan peran-peran dalam pernikahan.

Untuk menmperoleh temuan-temuan yang lebih spesifik dan analisis yang lebih mendalam mengenai tema penelitian sejenis di masa yang akan datang, dapat digunakan teori-teori dalam hubungan pernikahan. Hal ini agar aspekaspek yang lebih mencerminkan substansi dan dinamika yang khas dalam relasi pasangan suami-istri dengan isu pendapatan dapat lebih ditonjolkan sehingga dapat ditemukan alternatif solusi atas konflik yang terjadi dalam pernikahan pasangan suami-istri terkait isu pendapatan.

Data sekunder yang diperoleh dari keterangan orang-orang terdekat pasangan suami-istri dengan istri yang berpendapatan lebih besar dari suami, masih dibutuhkan lebih banyak lagi. Data ini dapat diperoleh melalui keterangan anak-anak dari para istri tersebut, bahkan dari pihak suami sebagai pasangan dari subjek penelitian ini untuk mendapatkan pemahaman yang lebih komprehensif mengenai realitas yang sesungguhnya terjadi pada pernikahan pasangan suami-istri dengan isu pendapatan di dalamnya. Penelitian dengan pendekatan kuantitaif juga dapat dikembangkan, misalnya mengenai pengaruh ekspektasi istri yang berpendapatan lebih besar dari suami mengenai peran suami terhadap pilihan untuk mempertahankan hubungan pernikahan.

Dalam relasi pasangan suami-istri dengan istri yang berpendapatan lebih besar dari suami, ketika muncul potensi konflik atau telah terjadi konflik yang disebabkan oleh isu pendapatan, komunikasi yang efektif untuk mengutarakan perasaan masing-masing dibutuhkan oleh kedua belah pihak agar terbangun kesepahaman di antara keduanya. Kesepahaman ini akan lebih baik jika ditindaklanjuti dengan kesepakatan yang menjadi solusi dari tema konflik yang dihadapi. Kesepakatan tersebut hendaknya menjadi komitmen bagi suamiistri untuk dijalankan pasca kesepakatan dibuat. Selanjutnya, sebagai bagian terpenting, adalah evaluasi atas kesepakatan yang dijalani; apakah kedua belah pihak konsisten dengan komitmennya, atau mencederai kesepakatan sehingga memunculkan ketidaknyamanan dari pihak lainnya, bahkan berujung konflik kembali. Adanya evaluasi atas kesepakatan yang merupakan solusi dari konflik ini dibutuhkan untuk membuka ruang komunikasi kembali apabila terjadi inkonsistensi komitmen dari suami/istri di masa yang akan datang. 


\section{DAFTAR PUSTAKA}

Anggraeni, R. A. (2012). Pola relasi suami istri terkait dengan pembagian kerja dan pengambilan keputusan (studi kasus terhadap tiga keluarga dalam perubahan peran di keluarga). Skripsi Program Studi Sosiologi Universitas Indonesia.

Arliss, L. P. (1993). Contemporary family communication: messages and meanings. New York, St Martin's Press.

Basrowi, S. (2002). Metode penelitian kualitatif perspektif mikro. Surabaya, Insan Cendikia.

Beebe, A. S. \& Beebe, S. J. (1986). Interpersonal communication relating to others. USA, Sage Publication, Ltd.

Berger, P. L. \& Luckmann, T. (2013). Tafsir sosial atas kenyataan risalah tentang sosiologi pengetahuan. Jakarta: Penerbit LP3ES

Creswell, J. W. (1997). Qualitatice inquiry and research design: choosing among five tradition. Sage: Thousand Oaks.

Denzin, N.K \& Lincoln, Y.S. (2009). Handbook of qualitative research. California, Sage Publications.
Finchman, F.D. (2004). Communication in marriage, in vangelisty, A.L (Ed), handbook of family communication. New York, LEA.

Heryadi, H. \& Silvana, H. (2013). Komunikasi antarbudaya dalam masyarakat multikultur. Diakses dari http://jurnal.unpad. ac.id/jkk/article/view/6034/3145

Ihromi, T. O. (1999). Bunga rampai sosiologi keluarga. Jakarta: Yayasan Obor Indonesia anggota IKAPI.

Kompasiana. (2015). Ketika penghasilan istri lebihtinggidarisuami.Diaksesdarihttp:// www.kompasiana.com/pakcah/ketikapenghasilan-istri-lebih-tinggi-darisuami 54f34cdf7455137c2b6c705f 24 November 2015, pkl 11:56 WIB

Littlejohn, S. \& Foss, K. A. (2005). Theories of human communication. Singapore, Thomson \& Wadsworth.

Schutz, A. (1972). the phenomenology of the social world. London: Heinemann Educational Books.

Segrin, C \& Flora, J. (2005). Family communication. New York, LEA.

West, R. \& Turner L. H. (2006). Introducing communication theory: analysis \& application. New York, Mc-Graw Hill. 